\title{
The Emergent Salt Diapirs in the East Zagros, Iran
}

\author{
Ghazaleh Razaghian1*, Mehran Arian² \\ ${ }^{1}$ Department of Geology, Damavand Branch, Islamic Azad University, Damavand, Iran \\ ${ }^{2}$ Department of Geology, Science and Research Branch, Islamic Azad University, Tehran, Iran \\ Email: "gh razaghian@yahoo.com
}

Received 23 August 2015; accepted 25 October 2015; published 29 October 2015

Copyright (C) 2015 by authors and Scientific Research Publishing Inc.

This work is licensed under the Creative Commons Attribution International License (CC BY). http://creativecommons.org/licenses/by/4.0/

(c) $($ )

\begin{abstract}
The emergent salt diapirs of the east Zagros, Iran have been investigated by their structural positions. The study area is including of Zagros orogeny belt and Persian Gulf that both of them have been formed on northeastern part of Arabian plate. There are 84 emergent salt diapirs that originated from Hormuz formation with Infra-Cambrian to Cambrian age. Based on location, shape and orientation of the emergent salt domes in the east Zagros hinterland and Persian Gulf foreland basin, internal motivation forces in the salt deposits has been predominant compared to later tectonic forces. In the other words, most of the emergent salt diapirs are pre-orogenic diapirs and they had got prominent role as pines in determining the shape and location of next structures during to the Zagros orogeny. Finally, Neogene continental collision has a supplementary role to diapirism and salt reactivation. However there are an evidence to syn-orogenic emergent diapirs that they have got an important role in the progressive deformation.
\end{abstract}

\section{Keywords}

Emergent, Diapirs, Tectonics, Zagros, Iran

\section{Introduction}

Investigation of emergent salt diapirs in the east Zagros region in Iran (Figure 1), is the main purpose of this research. Dominant structural trend in the study area is E-W. From tectonics point of view, it contains the overthrusted and simple folded belts of Zagros that formed on the northeastern part of Arabian plate's passive margin [1]-[3]. Zagros Mountains have been continued to East Taurus Mountains in Turkey and have named Zagros-East Taurus hinterland. Zagros-East Taurus hinterland is an external platform (fold and thrust belt) in north

*Corresponding author. 


\section{Physiographic-tectonic zoning map of Iran's sedimentary basins}

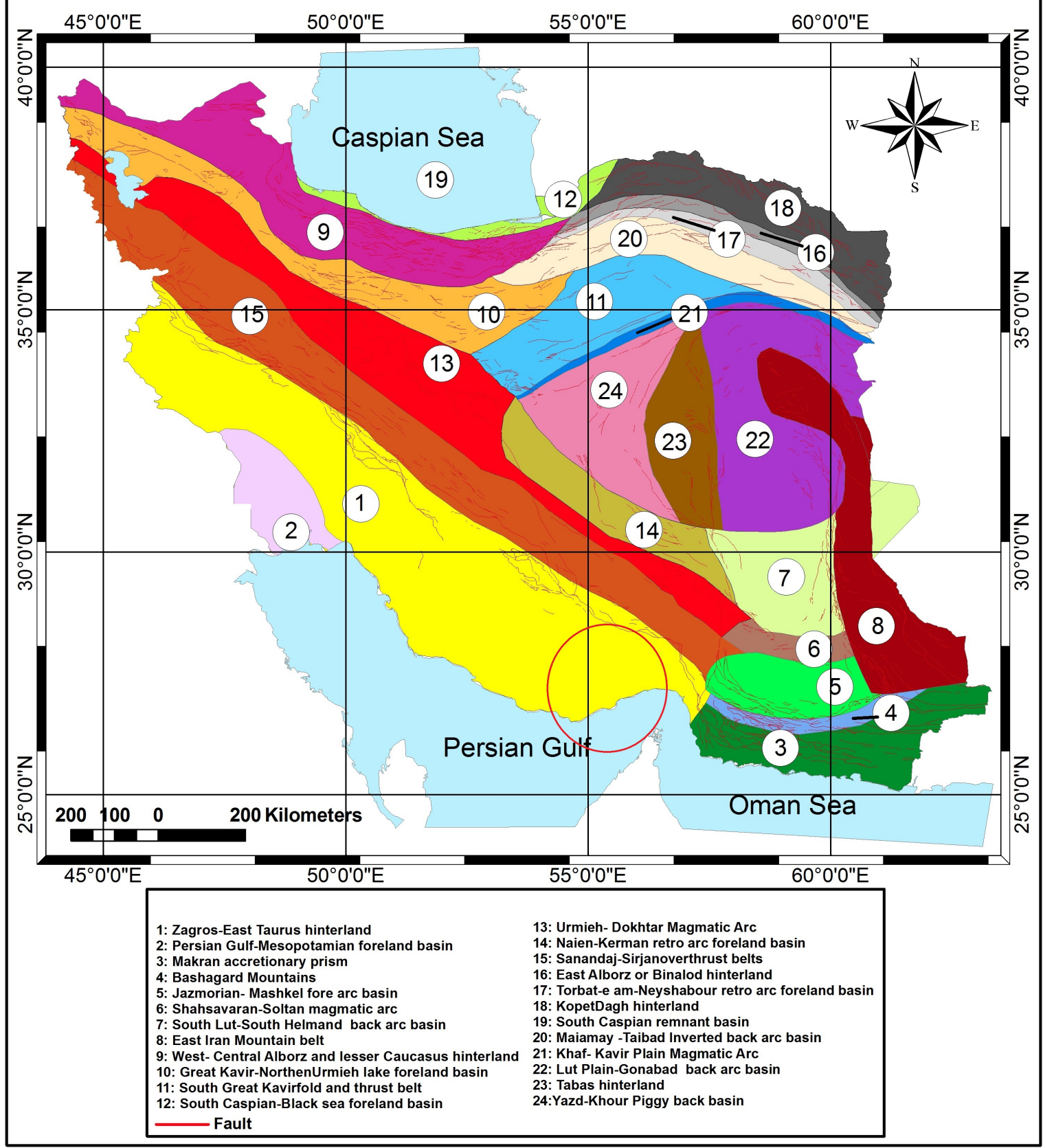

Figure 1. Physiographic-tectonic zoning map of Iran's sedimentary basins, modified from [1]. The study area is shown in the red circle.

margin of Arabian Craton. Vergence of folding in this hinterland is toward south and southwest.

The Hormuz Salt formation with Infra-Cambrian to Cambrian age had been deposited on northeastern part of Arabian plate. The name of the Hormuz salt with up to 1000 meters thickness was taken from the Iranian Hormuz Island, in the Persian Gulf.

Based on previous work on the salt and mud diapirism [4]-[15] and neotectonic regime in Iran [16]-[21], Zagros in south Iran is the most active zone [22]-[43]. Then, Alborz [44]-[83] and Central Iran [84]-[99] have been situated in the next orders. 


\section{Materials and Methods}

Neotectonic regime of the study area is due to the Neogene collision between the Arabian and Iranian plates [100]. The Zagros sedimentary rocks shows the syn-rifting facies of passive margin from the late Proterozoic to early Permian (Hormuz to Zakeen formations), post-rifting facies of passive margin from early Permian to the late Cretaceous (Faraghan to Gurpi formations) and foreland facies of syn-orogeny from the late Cretaceous to recent (Pabdeh to Bakhtyari formations) [101]. The sedimentary succession in the study area has got about 10 $\mathrm{km}$ thickness. Some of emergent salt diapirs are pre-orogenic, because they are situating far away related to orogenic belts, too. The salt islands such as Abu Musa, Tonb-e Bozorg and Tonb-e Kochak are the best example of these salt diapirs. Also, there is another interesting phenomena that is related to some emergent salt diapirs. The Banded Iron Formation or BIF on top of Hormuz salts is an evidence to rifting stage or intense subsidence in the continental passive margin.

Emergent salt diapirs of the east Zagros have got different shapes and sizes. These different morphologies are controlled by various factors, for example, position related to other structures, the time of emergence, the rate of salt dissolution, which is controlled by the rate of erosion, the bulk rate of salt emission from the source layer, and eventually by the tectonic activity [102]. These emergent salt diapirs of Zagros can be divided into two regions: The first region is Zagros hinterland with 74 emergent diapirs. The second region is north margin of Persian Gulf, with 10 emergent diapirs.

\section{Results and Discussion}

There are 84 emergent diapirs that can be considered as the most extensive salt basin of Zagros. Because, based on previous studies, such as [103], there are six type salt diapirs by investigation of the present-day surface morphology of them. They believe that nearly all the diapirs of the study area were already active prior to Zagros folding either as emergent diapirs forming islands in the Paleogene to Neogene Sea or as buried domes initiated at least by the Permian. They have been reactivated by subsequent tectonic events.

Therefore, most of salt domes are pre-orogenic emergent diapirs, and had a prominent role in determining the shape and location of folds during the Zagros orogeny. The position of some salt diapirs which they have been located on the plunging noses of anticlines (Figure 2) is an evidence to pine role of salt dome before the orogeny (Figure 3).

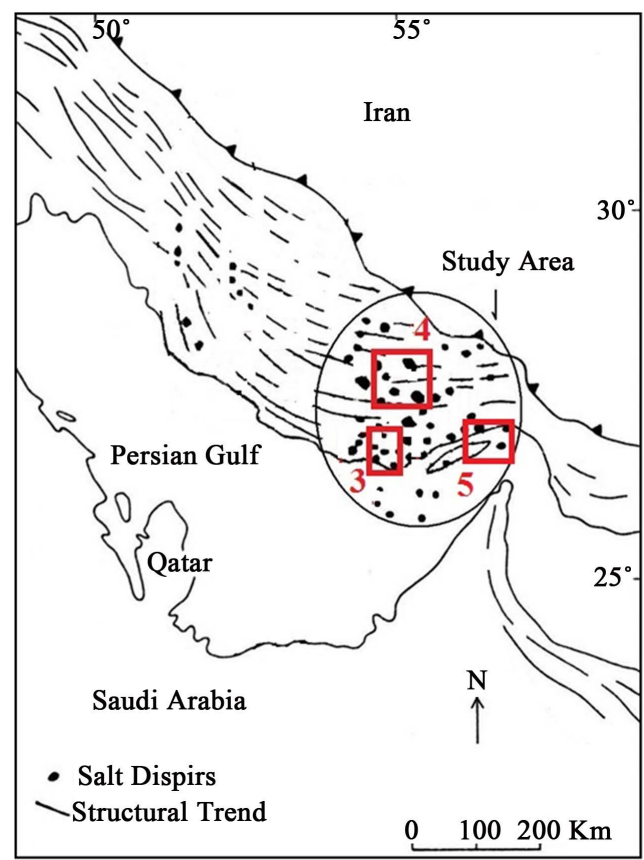

Figure 2. Geographical distribution of the salt diapirs in the east Zagros. Locations of Figures 3-5 have shown by red rectangles. 
It means that, they can be pre-orogenic emergent diapirs. But, there are several salt glaciers such as Chah Bano, Dehkuieh and Mazijan which some of them such as Gach and Burkh have been flowed on the limbs of anticlines (Figure 4). Therefore, they can be syn -orogenic emergent diapirs because their shape and location have been controlled by folds and faults interactions during orogeny. These salt structures are the more active and they have got an important role in the progressive deformation of faults and folds.

Also, there is another interesting phenomena that are related to some emergent salt diapirs. The islands such as Hormuz, Larak and Hengam (Figure 5) which are evidences to Halokinesis or internal trigger are predominant compared to tectonic processes or external trigger in these parts. Because they are very far from the Zagros suture zone.

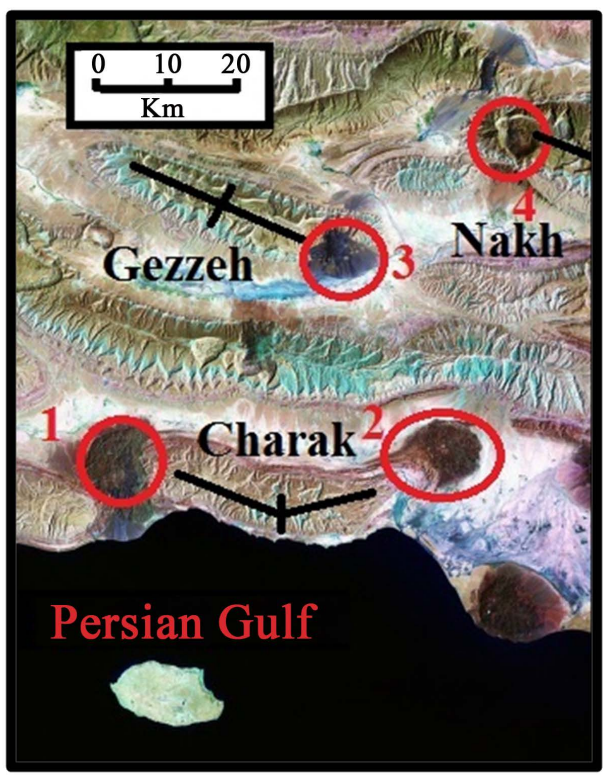

Figure 3. Interpreted ETM+ Satellite Image of salt diapirs (1: Kalat, 2: Charak, 3: Darbast, 4: Bastak) on the plunging noses of charak, Gezzeh and Nakh anticlines. Map located in Figure 2.

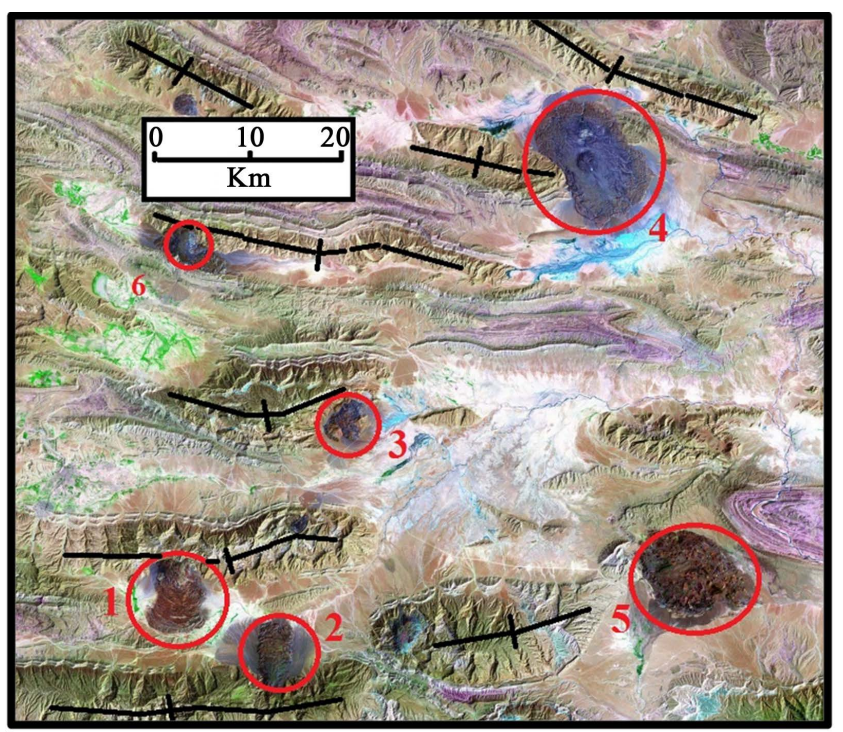

Figure 4. Interpreted ETM+ Satellite Image of the main salt glaciers (1: Gach, 2: Burkh, 3: Kurdeh, 4: Mazijan, 5: Chah Bano, 6: Dehkuieh) related to anticlines. Map located in Figure 2. 


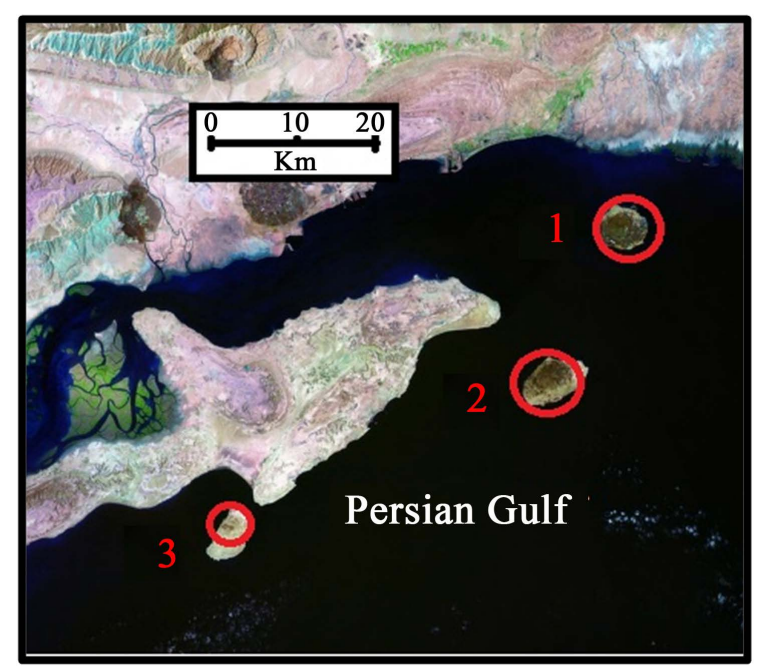

Figure 5. Interpreted ETM+ Satellite Image of some salt islands (1: Hormuz, 2: Larak, 3: Hengam in the Persian Gulf. Map located in Figure 2.

\section{Conclusions}

Based on the shape and orientation of emergent salt domes in the east Zagros, although salt diapirism has effected by collision forces, but it has not triggered by it. It means that Halokinesis (internal trigger) are predominant compared to tectonic processes (external trigger) in the east Zagros and Persian Gulf. Therefore, rifting event at Paleozoic is the main factor to Hormuz diapirism in the Zagros and Persian Gulf.

Hormuz diapirs have an important role for structural positions because most of them are pre-orogenic emergent diapirs and have a prominent role in determining the shape and the location of the next structure as a pine during the Zagros orogeny. Finally, Neogene continental collision has a supplementary role to diapirism and salt reactivation. However, there is an evidence to synorogenic emergent diapirs that they have got an important role in the progressive deformation of faults and folds.

\section{Acknowledgements}

This work has funded by department of geology, Damavand branch, Islamic Azad University, Damavand, Iran.

\section{References}

[1] Arian, M. (2013) Physiographic-Tectonic Zoning of Iran’s Sedimentary Basins. Open Journal of Geology, 3, $169-177$. http://dx.doi.org/10.4236/ojg.2013.33020

[2] Qorashi, M. and Arian, M. (2011) Tectonics of Iran. Geologic Survey of Iran, Tehran, 336 p.

[3] Arian, M. (2011) Basement Tectonics and Geology of Iran. Asar Nafis Press, Qum, 300 p.

[4] Arian, M. (2011) A Preface on Salt Diapirism of Iran. Asar Nafis Press, Qum, 309 p.

[5] Arian, M. and Noroozpour, H. (2015) The Biggest Salt-Tongue Canopy of Central Iran. Open Journal of Geology, 5, 55-60. http://dx.doi.org/10.4236/ojg.2015.52005

[6] Asadian, F., Pourkermani, M. and Arian, M. (2007) Tectonic Geomorphology of Salt Structures in the GarmsarLasjerd Area. Geographical Research, 39, 75-84.

[7] Pourkermani, M. and Arian, M. (1997) Salt Domes of Central Iran. Journal of Humanities, 3, 29-41.

[8] Arian, M. (2012) Salt Diapirism and Tectonics. Asar Nafis Press, Second Edition, Qum, 319 p.

[9] Arian, M. and Noroozpour, H. (2015) Tectonic Geomorphology of Iran's Salt Structures. Open Journal of Geology, 5, 61-72. http://dx.doi.org/10.4236/ojg.2015.52006

[10] Asadian, F. and Arian, M. (2009) Identification of Diapiric Provinces of Central Iran through Geological and Geographical Analysis. International Journal of Agriculture Environment \& Biotechnology, 2, 3443-3451.

[11] Arian, M. (2012) Clustering of Diapiric Provinces in the Central Iran Basin. Carbonates and Evaporites, 27, 9-18. http://dx.doi.org/10.1007/s13146-011-0079-9 
[12] Pourkermani, M. and Arian, M. (1998) Tectonic Geomorphology of Salt Domes in West of Zanjan Province, Iran. Geographical Research, 47, 44-53.

[13] Arian, M. and Feizi, F. (2010) The Significance of Faulting on the Surficial Spreading of Evaporitic Deposits in the Varamin-Semnan Area. Journal of Earth and Resources, 3, 1-20.

[14] Feizi, F., Arian, M. and Arian, A. (2015) Mud Diapirism on the Makran, Iran: Case Study on the Napag Mud Volcano. Open Journal of Geology, 5, 300-308. http://dx.doi.org/10.4236/ojg.2015.55027

[15] Arian, M. and Sistanipour, A. (2015) Mud Diapirism on the Gorgan. North Iran Open Journal of Geology, 5, $442-450$. http://dx.doi.org/10.4236/ojg.2015.56041

[16] Arian, M. and Khodabakhshnezhad, A. (2015) Sedimentary Environments Can Be Changed by Geotechnology (Case Study: A Morphotectonic Idea for Design of Extensive Artificial Bay on the Iranian Plateau). International Journal of Geosciences, 6, 487-496. http://dx.doi.org/10.4236/ijg.2015.65039

[17] Arian, M. (2011) Middle East Tectonics. Asar Nafis Press, Qum, 236 p.

[18] Arian, M. (2010) Applied Seismotectonics. Farazamin Press, Tehran, 304 p.

[19] Arian, M. and Maleki, R. (2008) Neotectonics. Farazamin Research Center, Tehran, 150.

[20] Pourkermani, M. and Arian, M. (1998) Seismicity of Iran. Shahid Beheshti University Press, Tehran, 212.

[21] Pourkermani, M. and Arian, M. (1997) Seismotectonics. Dez Ab Consulting Engineers Company Press, Tehran, 270.

[22] Arian, M. and Aram, Z. (2014) Relative Tectonic Activity Classification in the Kermanshah Area, Western Iran. Solid Earth, 5, 1277-1291. http://dx.doi.org/10.5194/se-5-1277-2014

[23] Mashal, M., Pour Kermani, M., Charchi, A., Almasian, M. and Arian, M. (2013) Pattern of Structural Geology Underground in Eastern of North Dezfol Embayment. Advances in Environmental Biology, 7, 260-268.

[24] Pazhoohan, M., Arian, M., Ghorashi, M. and Khosrotehrani, K. (2014) A Study of Drainage Pattern Responses to Active Tectonics in Tadvan Region, SW Iran. Geodynamics, 1, 36-41.

[25] Rahimi, N. and Arian, M. (2014) Tectonic Geomorphology of Kangavar-Sosangerd Region, West Iran. Advances in Environmental Biology, 8, 119-124.

[26] Arian, M. and Hashemi, A. (2008) Seismotectonic Zoning in the Zagros. Journal of Sciences, 18, 63-76.

[27] Arian, M., Ahmadnia, A., Qorashi, M. and Pourkermani, M. (2002) Structural Analysis of Mengharak Transcurrent Fault System in Zagros, Iran. Special Geo 2002 Conference Issue Geoarabia, 7, 209-210.

[28] Arian, M., Qorashi, M., Pourkermani, M. and Ahmadnia, A. (2003) Fractal Analysis of Mengharak Transcurrent Fault System in Zagros, Iran. Proceedings of the Fourth International Conference on Seismology and Earthquake Engineering, Tehran, 12-14 May 2003, 23.

[29] Baharvand, S., Pourkermani, M., Ajalloian, R., Arian, M. and Nouryazdan, A.R. (2010) Seymareh Landslide and Its Role in Environmental and Geomorphologic Changes of the Pole-Dokhtar Area. Journal of the Earth, 4, 13-24.

[30] Abdideh, M., Qorashi, M., Rangzan, K. and Arian, M. (2011) Assessment of Relative Active Tectonics Using Morphometric Analysis, Case Study of Dez River (Southwestern, Iran). Geosciences, 20, 33-46.

[31] Arian, M., Qorashi, M., Pourkermani, M. and Ahmadnia, A. (2006) The Structural Significance Kareh Bas Transcurrent Fault System in the Zagros Fold and Thrust Belt. Geosciences, 15, 126-133.

[32] Arian, M. and Noroozpour, H. (2015) Seismic Activity and Fractal Geometry of Kareh Bas Fault System in Zagros, South of Iran. Open Journal of Geology, 5, 291-299. http://dx.doi.org/10.4236/ojg.2015.55026

[33] Ehsani, J. and Arian, M. (2015) Quantitative Analysis of Relative Tectonic Activity in the Jarahi-Hendijan Basin Area, Zagros Iran. Geosciences Journal, 19, 1-15. http://dx.doi.org/10.1007/s12303-015-0016-3

[34] Omidali, M., Arian, M. and Sorbi, A. (2015) Neotectonics of Boroujerd Area, SW Iran by Index of Active Tectonics. Open Journal of Geology, 5, 309-324. http://dx.doi.org/10.4236/ojg.2015.55028

[35] Chegini, A., Sorbi, A. and Arian, M. (2015) Active Tectonics of Hamedan Area, West Iran. International Journal of Geography and Geology, 4, 109-128.

[36] Maleki, Z., Arian, M., Solgi, A. and Ganjavian, M.A. (2014) The Elements of Fold Style Analysis in the Khaftar Anticline, Zagros, Iran. Open Journal of Geology, 4, 79-92. http://dx.doi.org/10.4236/ojg.2014.43008

[37] Maleki, Z., Arian, M. and Solgi, A. (2014) Structural Style and Hydrocarbon Trap of Karbasi Anticline, in the Interior Fars Region, Zagros, Iran. Solid Earth Discussions, 6, 2143-2167. http://dx.doi.org/10.5194/sed-6-2143-2014

[38] Ehsani, J., Arian, M. and Ghorashi, M. (2015) Geomorphic Signatures of Active Tectonics in the Jarahi-Hendijan Drainage Basin in the South West Iran. Geosciences, 24, 211-218.

[39] Khodabakhshnezhad, A., Pourkermani, M., Arian, M., Matkan, A.A. and Charchi, A. (2015) Active Tectonics of Great Karoun River Basin. Geosciences, 24, 13-28. 
[40] Maleki, Z., Arian, M., Solgi, A. and Ganjavian, M.A. (2015) Elements of Fold Style Analysis in the Karbasi Anticline, Interior Fars Region, Zagros. Geosciences, 24, 293-302.

[41] Baratpour, F., Arian, M. and Solgi, A. (2015) Geometric Analysis of Tukak and Kamarun Anticlines on Izeh Zone, Zagros. Geosciences, 24, 191-200.

[42] Gholamhosein Fard, N., Sorbi, A. and Arian, M. (2015) Active Tectonics of Kangavar Area, West Iran. Open Journal of Geology, 5, 422-441. http://dx.doi.org/10.4236/ojg.2015.56040

[43] Maleki, Z., Arian, M. and Solgi, A. (2015) Folding Pattern in the Fars Province, Zagros Folded Belt: Case Study on the Karbasi and Khaftar Anticlines, Interior Fars, Iran. Solid Earth Discussions, 7, 2347-2379. http://dx.doi.org/10.5194/sed-7-2347-2015

[44] Alladin, Y., Talebian, M., Arian, M. and Ahmadi, M.M. (2015) Geotechnical Investigation and Seismic Zonation of Alluvial Deposits in Western Tehran. Geosciences, 24, 333-342.

[45] Taherkhani, B., Nazari, H., Pourkermani, M. and Arian, M. (2015) Geometry and Recent Kinematics of the North Qazvin Fault: Morphotectonic Approach. Geosciences, 24, 29-38.

[46] Manuchehri, H., Arian, M., Ghorashi, M., Solgi, M. and Sorbi, A. (2015) Geomorphic Signatures of Active Tectonics in the Chalus Drainage Basin in the Alborz, Iran. Geosciences, 24, 273-280.

[47] Noroozpour, H., Arian, M. and Sorbi, A. (2015) Fault Movement Potentials in the Tehran-Semnan Region (North Iran). Open Journal of Geology, 5, 281-290. http://dx.doi.org/10.4236/ojg.2015.55025

[48] Arian, M., Maleki, Z. and Noroozpour, H. (2011) Cenozoic Diastrophism and Deformational Events in the East Central Alborz. Journal of Basic and Applied Scientific Research, 1, 2394-2400.

[49] Feizi, F., Arian, A. and Rahmani, R. (2007) Seismotectonic Zoning in the Eastern Part of the Central Alborz. Journal of Sciences, 17, 151-164.

[50] Khavari, R., Arian, M. and Ghorashi, M. (2009) Neotectonics of the South Central Alborz Drainage Basin, in NW Tehran, N Iran. Journal of Applied Sciences, 9, 4115-4126. http://dx.doi.org/10.3923/jas.2009.4115.4126

[51] Arian, M. and Bagha, N. (2012) Active Tectonics of Tehran Area, Iran. Journal of Basic and Applied Scientific Research, 2, 3805-3819.

[52] Bagha, N., Arian, M., Ghorashi, M., Pourkermani, M., El Hamdouni, R. and Solgi, A. (2014) Evaluation of Relative Tectonic Activity in the Tehran Basin, Central Alborz, Northern Iran. Geomorphology, 213, 66-87. http://dx.doi.org/10.1016/j.geomorph.2013.12.041

[53] Arian, M. and Feizi, F. (2005) Application of Geomorphic Indices to the Assessment of Relative Tectonic Activity Levels in the Alborz-Central Iran Border Zone. Journal of Sciences, 15, 378-403.

[54] Arian, M., Bagha, N., Khavari, R. and Noroozpour, H. (2012) Seismic Sources and Neo-Tectonics of Tehran Area (North Iran). Indian Journal of Science and Technology, 5, 2379-2383.

[55] Moghimi, H., Arian, M. and Sorbi, A. (2015) Fault Movement Potential of Marzanabad Area, North Alborz, Iran. Open Journal of Geology, 5, 126-135. http://dx.doi.org/10.4236/ojg.2015.53012

[56] Arian, M. and Pourkermani, M. (2004) Tectonic Elements of South Flank in the East-Central Alborz Mountain. Journal of Sciences, Teacher Training University, 4, 359-368.

[57] Arian, M. and Qorashi, M. (2006) The Movement Potential Evaluation of the Major Quaternary Faults in Alborz-Central Iran Border Zone, from the East of Tehran to the East of Semnan. Journal of Geosciences, Geological Survey of Iran, 15, 184-188.

[58] Poroohan, N., Pourkermani, M. and Arian, M. (2013) An Assessment of Relationship in F-Parameter and Paleostress Fields in Heterogeneous Lithologies: Roudbar Area (Northwest of Iran). Australian Journal of Basic \& Applied Sciences, 7, 933-942.

[59] Poroohan, N., Poukermani, M. and Arian, M. (2009) An Assessment on Correlations of Seismotectonic Parameters Preceding and Following Roudbar-Manjil Earthquake (Gilan, North of Iran). Australian Journal of Basic \& Applied Sciences, 3, 2643-2652.

[60] Farrokhnia, A.R., Pirasteh, S., Pourkermani, M. and Arian, M. (2011) Geo-Information Technology for Mass Wasting Hazard Zonation: Central-West Alborz-Iran. Disaster Advances, 4, 24-33.

[61] Khavari, R., Ghorashi, M. and Arian, M. (2009) Assessment of Relative Active Tectonics, South Central Alborz (North Iran). EGU General Assembly Conference Abstracts, 11, 1137.

[62] Sorbi, A., Arian, M. and Pourkermani, M. (2009) The Movement Potential Evaluation of the Major Quaternary Faults in Tehran Quadrangle. Journal of the Earth, 19, 176-182.

[63] Feizi, F. and Arian, M. (2006) The Classification of Thrust Fronts in the Alborz-Central Iran Border Zone from the East of Varamin to the East of Semnan. Journal of Sciences, 16, 75-87. 
[64] Sadeghi, R., Saeedi, A., Arian, M., Ghorashi, M. and Solgi, A. (2015) Comparison of Strain Ellipsoid Shape in the South of Ardabil Range (NW), Based on the Results of the Magnetic Susceptibility Anisotropy and Paleostress Methods. Open Journal of Geology, 5, 611-622. http://dx.doi.org/10.4236/ojg.2015.59054

[65] Arian, M. and Pourkermani, M. (2004) Structural Significance of North Semnan and Attary Faults in Alborz-Central Iran Border Zone. Journal of Science, 14, 4551-4569.

[66] Arian, M. and Pourkermani, M. (2005) Cenozoic Diastrophism and Deformational Events in the Southern Flank of Central-East Alborz. Journal of Faculty Earth Sciences, 10, 43-51.

[67] Arian, M., Pourkermani, M., Qorashi, M. and Ghasemi, M.R. (2003) North Semnan Fault System and Its Role on Basin Division. Proceedings of the 8th Symposium of Geological Society of Iran, Shahrood, 4-6 September 2003, 11-17.

[68] Pourkermani, M. and Arian, M. (2001) Structural Geomorphology of Northeastern Kurdistan. Journal of Humanities, 7, 37-48.

[69] Mardani, Z., Ghorashi, M. and Arian, M. (2011) Geomorphic Signatures of Active Tectonics in the Talaghanrud, Shahrudand Sefidrud Drainage Basins in Central Alborz, N Iran. Geosciences, 20, 159-166.

[70] Sorbi, A., Arian, M. and Pourkermani, M. (2011) The Application of Geomorphic Indices to the Assessment of Relative Tectonic Activity Levels in Tehran Quadrangle. Journal of the Earth, 6, 1-9.

[71] Khavari, R., Ghorashi, M., Arian, M. and Khosrotehrani, K. (2010) Geomorphic Signatures of Active Tectonics in the Karaj Drainage Basin in South Central Alborz, N Iran. Geosciences, 19, 67-74.

[72] Javadi Mousavi, E. and Arian, M. (2015) Tectonic Geomorphology of Atrak River, NE Iran. Open Journal of Geology, 5, 106-114. http://dx.doi.org/10.4236/ojg.2015.53010

[73] Nouri, R., Jafari, M.R., Arian, M., Feizi, F. and Afzal, P. (2013) Correlation between Cu Mineralization and Major Faults Using Multifractal Modelling in the Tarom Area (NW Iran). Geologica Carpathica, 64, 409-416. http://dx.doi.org/10.2478/geoca-2013-0028

[74] Nouri, R., Jafari, M.R., Arian, M., Feizi, F. and Afzal, P. (2013) Prospection for Copper Mineralization with Contribution of Remote Sensing, Geochemical and Mineralographical Data in Abhar 1:100,000 Sheet, NW Iran. Archives of Mining Sciences, 58, 1071-1084. http://dx.doi.org/10.2478/amsc-2013-0074

[75] Nouri, R., Afzal, P., Arian, M., Jafari, M. and Feizi, F. (2013) Reconnaissance of Copper and Gold Mineralization Using Analytical Hierarchy Process in the Rudbar 1: 100,000 Map Sheet, Northwest Iran. Journal of Mining and Metallurgy, 49, 9-19.

[76] Farrokhnia, A.R., Pirasteh, S., Pradhan, B., Pourkermani, M. and Arian, M. (2011) A Recent Scenario of Mass Wasting and Its Impact on the Transportation in Alborz Mountains, Iran Using Geo-Information Technology. Arabian Journal of Geosciences, 4, 1337-1349. http://dx.doi.org/10.1007/s12517-010-0238-7

[77] Arian, M. and Nouri, R. (2015) Lineament Tectonics and Mineralization in Tarom Area, North Iran. Open Journal of Geology, 5, 115-124. http://dx.doi.org/10.4236/ojg.2015.53011

[78] Feizi, F. and Arian, M. (2011) The Role of Structural Controllers in Geneses of Copper Deposits in 1:50,000 Map of Saiin Qaleh. Journal of Sciences, 21, 1-10.

[79] Arian, M., Qorashi, M. and Ahmadnia, A. (2003) Analysis of Behbahan Shear Zone. Iranian journal of Geology, 1, 14.

[80] Bahiraee, S., Arian, M., Qorashi, M. and Solgi, M. (2015) The Movement Potential Evaluation of the Mosha Fault (The West of Firoozkuh to the Shahrestanak). Geosciences, 24, 123-126.

[81] Bagha, N., Ghorashi, M., Arian, M., Pourkermani, M. and Solgi, A. (2015) Neotectonic Analysis of Mosha-North Tehran Fault Zone, Based on Morphotectonic Features, Central Alborz, Northern Iran. Geosciences, 24, 41-52.

[82] Mosavi, E. and Arian, M. (2015) Neotectonics of Kashaf Rud River, NE Iran by Modified Index of Active Tectonics (MIAT). International Journal of Geosciences, 6, 776-794. http://dx.doi.org/10.4236/ijg.2015.67063

[83] Nouri, R. and Arian, M. (2015) Structural Control on the Distribution of Hydrothermal Alteration Zones and Mineralization in Dastjerdeh Area Based on Remote Sensing Data, NW Iran. Bulletin of the Georgian National Academy of Sciences, 9, 79-86.

[84] Sistanipour, A. and Arian, M. (2015) Geometric Analysis of Davaran Fault System, Central Iran. Open Journal of Geology, 5, 458-469. http://dx.doi.org/10.4236/ojg.2015.56043

[85] Nazemi, M., Ghorashi, M., Ghassemi, M.R. and Arian, M. (2015) Morphotectonics Features of Alluvial Fans Associated with Active Tectonics (Shotori Mountains, East of Tabas-Central Iran). Geosciences, 24, 91-100.

[86] Alizadeh, H. and Arian, M. (2015) Rule of Structural Factors in Formation of Porphyry Copper Deposits in South western Part of Kerman Area, Iran. Open Journal of Geology, 5, 489-498. http://dx.doi.org/10.4236/ojg.2015.57045

[87] Javadi Mosavi, E. and Arian, M. (2015) Neotectonics of Tabas Area, Central Iran by Index of Active Tectonics (IAT). 
Open Journal of Geology, 5, 209-223. http://dx.doi.org/10.4236/ojg.2015.54019

[88] Daryani, N.J., Arian, M. and Omran, N.R. (2015) Tectonics and Mineralization of Copper in the Ardestan-Kahang Area, Central Iran by Remote Sensing. Open Journal of Geology, 5, 188-196. http://dx.doi.org/10.4236/ojg.2015.54017

[89] Arian, M. and Pourkermani, M. (2001) Rivers Morphology and Active Tectonic (Reviewing the Current Status of Ghezel Ozon River in the Province of Zanjan). Proceedings of the 5th Conference of Geological Society of Iran, Tehran, 28-30 August 2001, 556.

[90] Eshghi, Z., Arian, M. and Pourkermani, M. (2012) Structural Investigation on the Lak Mining Area (Bueen Zahra) Based on Remote Sensing, Used for Its Mineralization. Journal of the Earth, 6, 145-155.

[91] Arian, M., Toudeshki, V.H. and Noroozpour, H. (2011) Active Tectonics of Qezel Ozan River Basin, NW Iran. Journal of Applied Environmental and Biological Sciences, 1, 291-295.

[92] Alizadeh, H., Arian, M., Lotfi, M., Ghorashi, M. and Ghorbani, M. (2015) Determination of Porphyry Copper Deposit Locations Using Photo Lineament Factor in Northern Parts of the Dehaj-Sardoiyeh Belt. Geosciences, 24, $247-252$.

[93] Toudeshki, V.H., Pourkermani, M., Arian, M. and Khosrotehrani, K.H. (2011) Influence of Structures on the Ghezel Ozan River. Geosciences, 21, 55-60.

[94] Toudeshki, V.H. and Arian, M. (2011) Morphotectonic Analysis in the Ghezel Ozan River Basin, NW Iran. Journal of Geography and Geology, 3, 258-260. http://dx.doi.org/10.5539/jgg.v3n1p258

[95] Arian, M. (2015) Seismotectonic-Geologic Hazards Zoning of Iran. Earth Sciences Research Journal, 19, 7-13. http://dx.doi.org/10.15446/esrj.v19n1.40664

[96] Arian, M., Pourkermani, M., Sistanipour, A. and Noroozpour, H. (2011) Kinematic Significance of Fold- and FaultRelated Fracture Systems in the Rafsanjan’s Northeast Highlands (Central Iran). Journal of Basic and Applied Scientific Research, 1, 3398-3406.

[97] Arian, M., Pourkermani, M., Sistanipour, A. and Noroozpour, H. (2011) Seismicity and Fault Segmentation of BafqBaghin Fault System (Central Iran). Journal of Applied Environmental and Biological Sciences, 1, 382-396.

[98] Mosavi, E.J., Arian, M., Ghorashi, M. and Nazemi, M. (2012) Measurements of Geomorphic indices in Tabas Area. Journal of the Earth, 7, 213-225.

[99] Arian, M. (2010) Earthquake-Fault Hazard Investigations in the Kerman Quadrangle. Journal of Sciences, 19, $176-182$.

[100] Alavi, M. (2004) Regional Stratigraphy of the Zagros Fold and Thrust Belt of Iran and Its Proforeland Evolution. American Journal of Science, 304, 1-20. http://dx.doi.org/10.2475/ajs.304.1.1

[101] Arian, M. (2010) Tectonics and Sedimentation. Farazamin Press, Tehran, 307 p.

[102] Jahani, S., Callot, J.P., Frizon de Lamotte, D., Letouzey, J. and leturmy, P. (2007) The Salt Diapirs of the Eastern Fars Province (Zagros, Iran): A Brief Outline of Their Past and Present. Frontiers in Earth Sciences, 2, 289-308. http://dx.doi.org/10.1007/978-3-540-69426-7_15

[103] Jahani, S., Callot, J.P., Letouzey, J. and de Lamotte, D.F. (2009) The Eastern Termination of the Zagros Fold-andThrust Belt, Iran: Structures, Evolution, and Relationships between Salt Plugs, Folding and Faulting. Tectonics, $28,22$. http://dx.doi.org/10.1029/2008TC002418 